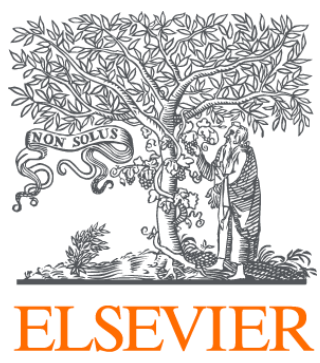

Since January 2020 Elsevier has created a COVID-19 resource centre with free information in English and Mandarin on the novel coronavirus COVID-

19. The COVID-19 resource centre is hosted on Elsevier Connect, the company's public news and information website.

Elsevier hereby grants permission to make all its COVID-19-related research that is available on the COVID-19 resource centre - including this research content - immediately available in PubMed Central and other publicly funded repositories, such as the WHO COVID database with rights for unrestricted research re-use and analyses in any form or by any means with acknowledgement of the original source. These permissions are granted for free by Elsevier for as long as the COVID-19 resource centre remains active. 


\title{
Response of Rat Tracheal Epithelium to Ozone and Oxygen Exposure in Vitro
}

\author{
KRISTEN J. NIKULA* AND DENNIS W. WILSON† \\ *Inhalation Toxicology Research Institute, Lovelace Biomedical and Environmental Research Institute, \\ P.O. Box 5890, Albuquerque, New Mexico 87185; and $\dagger$ Department of Pathology, School of \\ Veterinary Medicine, University of California, Davis, California 95616
}

Received September 22, 1989; accepted January 22, 1990

\begin{abstract}
Response of Rat Tracheal Epithelium to Ozone and Oxygen Exposure in Vitro. NIKULA, K. J., AND Wilson, D. W. (1990). Fundam. Appl. Toxicol. 15, 121-131. Although ozone-induced epithelial injury in vivo has been morphologically characterized, effects of gaseous oxidants on respiratory epithelium in organ culture, where tissue organization is maintained but systemic influences are eliminated, have not been thoroughly investigated. In this study, we exposed tracheal organ cultures from rats to $95 \%$ oxygen and 1 ppm ozone, alone and in combination, to determine (1) whether epithelial responses to ozone similar to those observed in vivo occur in airways separated from systemic physiologic, secretory, and inflammatory reactions; (2) whether concentrations of oxygen sufficient to potentially cause oxidant injury result in morphologic epithelial alterations similar to those that occur in ozone toxicity; and (3) if the combined oxidant insult of oxygen and ozone results in more severe damage to the tracheal epithelium than occurs with ozone in air. Tracheal organ cultures were exposed to filtered air and $5 \%$ carbon dioxide; filtered air, $5 \%$ carbon dioxide, and 1 ppm ozone; $95 \%$ oxygen and $5 \%$ carbon dioxide; or $95 \%$ oxygen, $5 \%$ carbon dioxide, and $1 \mathrm{ppm}$ ozone for $96 \mathrm{hr}$. Light- and quantitative electron-microscopic evaluation showed that epithelia exposed to $1 \mathrm{ppm}$ ozone in air exhibited loss of ciliated cells and ciliated cell damage. The epithelia exposed to $95 \%$ oxygen and 5\% carbon dioxide were pseudostratified, columnar, ciliated, and hyperplastic. Epithelia exposed to $95 \%$ oxygen plus $1 \mathrm{ppm}$ ozone were stratified and nonciliated or very sparsely ciliated. The predominant cell types in epithelia exposed to oxygen plus ozone were serous cells and metaplastic cells, and focal aggregates of adherent necrotic cells were present. We conclude that there was a synergism between oxygen and ozone exposure leading to enhanced epithelial injury and metaplasia. 1990 Society of Toxicology
\end{abstract}

\section{INTRODUCTION}

The epithelium lining the trachea, bronchioles, and alveoli is potentially exposed to and injured by oxidant gases. Two common oxidant exposures are ozone, the major oxidant in photochemical smog, and oxygen, used therapeutically. Morphologic responses of the extrapulmonary respiratory epithelium to ozone exposure in vivo include ciliary damage, necrosis, and loss of ciliated cells, presence of intermediate cells, hyperplasia, and shifts in cell population densities (Nikula $e t$ al., 1988; Wilson et al., 1984; Harkema et al., 1987). Inflammation accompanies these lesions (Harkema et al., 1987). The location and intensity of these responses depend on the ozone concentration, animal species, duration of exposure, and time postexposure. Morphologic responses of extrapulmonary airways to oxygen exposure in vivo have been less well documented. Alterations noted in rat tracheal epithelium after acute exposures to $100 \%$ oxygen have included ciliogenesis 
(Heino and Laitinen, 1982) and presence of compound cilia and swelling of nonciliated cells (Philpott et al. 1977). Acute tracheitis has been reported as a consequence of hyperoxia in dogs (Sackner et al., 1976) and humans (Sackner et al., 1975).

Despite a number of organ culture studies, in vitro exposures of respiratory epithelium to gaseous oxidants have rarely been reported. The effects on human neonatal tracheal epithelium of atmospheres containing 20 or $80 \%$ oxygen have been compared (Boat et al., 1973; Boat, 1979). Ozone-induced changes in the rate of glycoprotein secretion into the culture medium have been studied using in vivo exposures and subsequent culture of the preexposed tracheas (Last et al., 1977). Similarly, in vivo exposures followed by culture of the preexposed tracheas have been used to examine the effects of ozone and sulfuric acid on ciliary beat frequency (Grose et al., 1980). When evaluating organ culture exposure systems, it must be remembered that solution of oxidant gases in the overlying medium does not resemble exposure conditions in vivo and is not suitable for studying the effects of poorly soluble oxidant gases (Rasmussen, 1984). The toxic species causing cell injury may be different depending on whether the reactive compounds diffuse through a thin layer or a relatively thick layer of medium before reaching the cells (Morgan and Wenzel, 1985). We have characterized the effects of ozone exposure on tracheal epithelium in vivo (Wilson et al., 1984; Nikula et al., 1988). In the present study, we have exposed tracheal organ cultures from rats to $95 \%$ oxygen and $1 \mathrm{ppm}$ ozone, alone and in combination, to determine (1) whether epithelial responses to ozone similar to those observed in vivo occur in airways separated from systemic physiologic, secretory, and inflammatory reactions; (2) whether concentrations of oxygen sufficient to potentially cause oxidant injury result in morphologic epithelial alterations similar to those that occur in ozone toxicity; and (3) if the combined oxidant insult of oxy- gen and ozone result in more severe damage to the tracheal epithelium than that which occurs with ozone in air.

\section{MATERIALS AND METHODS}

Animals. Twenty disease-free male Sprague-Dawley rats weighing 250-270 $\mathrm{g}$ were purchased from Bantin and Kingman (Fremont, CA), and maintained on Purina rodent laboratory chow No. 5001 and water ad libitum. They were serologically determined to be free of antibodies to pneumonia virus of mice, reovirus 3 , Theiler's virus, Sendai virus, Kilham rat virus, $\mathrm{H}-\mathrm{I}$ virus, rat corona virus/sialodacryoadenitits virus, and Mycoplasma pulmonis (Microbiological Associates, Bethesda, MD).

Organ culture exposures. The rats were euthanized by sodium pentobarbital ( $250 \mathrm{mg} / \mathrm{kg}$ intraperitoneally) injection and their entire tracheas were removed. The tracheas were cut longitudinally through the cartilaginous portion and placed epithelial side up on a stainless-steel grid in individual $10-\mathrm{ml}$ glass vials containing $2 \mathrm{ml}$ of culture medium (Dulbecco's minimal Eagle (GIBCO. Grand Island, NY) supplemented with L-glutamine (2 $\mathrm{mM})$, gentamicin $(20 \mu \mathrm{g} / \mathrm{ml})$, and amphotericin B $(2.5$ $\mu \mathrm{g} / \mathrm{ml}$ ). No serum was added to the medium. The vials were placed in $320-\mathrm{ml}$ exposure vessels (five vials per vessel) mounted on a rocking platform in a culture system where, due to the rocking action ( 12 cycles/min), the epithelial surfaces were intermittently directly exposed to the experimental atmosphere saturated with water vapor, and held at $37^{\circ} \mathrm{C}$. Four atmospheres were used: biologically and chemically filtered air and $5 \%$ carbon dioxide (air); filtered air, 5\% carbon dioxide, and 1 ppm ozone (air/ $\left./ \mathrm{O}_{3}\right) ; 95 \%$ oxygen and $5 \%$ carbon dioxide $\left(95 \% \mathrm{O}_{2}\right)$; and $95 \%$ oxygen, $5 \%$ carbon dioxide, and 1 ppm ozone $\left(95 \% \mathrm{O}_{2} / \mathrm{O}_{3}\right)$. The total flow rate of each atmospherc through the exposure vessel was 3 liters $/ \mathrm{min}$. Total culture time was $96 \mathrm{hr}$, with removal of old medium and addition of fresh mediun every $24 \mathrm{hr}$. At the end of the incubation period, the tracheas were placed in $2 \%$ glutaraldehyde fixative and $0.1 \mathrm{M}$ cacodylic acid buffer ( $\mathrm{pH} 7.4$, 385 mOsm).

Exposure atmosphere generation and ozone monitoring. Most of the components of the system which the test atmospheres came in contact with were made from perfluoroalkoxy fluorocarbon (Teflon PFA). A few items were made of glass or type 316 stainless steel. The gases (filtered air, vaporized medical grade liquid oxygen, and dry $99.8 \%$ carbon dioxide) were introduced into the system at a stable pressure of $0.21 \mathrm{~kg} / \mathrm{cm}^{2}$. By adjusting the flow rate of the air or oxygen stream to 2.85 liters/ min and mixing with $150 \mathrm{cc} / \mathrm{min}$ carbon dioxide, a $5 \%$ by volume carbon dioxide atmosphere was maintained in a total flow rate of $3 \mathrm{liters} / \mathrm{min}$ through the air and $95 \%$ 
$\mathrm{O}_{2}$ exposure vessels. The ozone was generated by passing vaporized medical grade liquid oxygen through a silent arc discharge ozonizer to produce $60 \mathrm{ppm}$ ozone in the oxygen. Fifty cubic centimeters per minute of the ozone in oxygen stream was metered into the exposure portion of the system. Flow rates of $2.8 \mathrm{liters} / \mathrm{min}$ air or oxygen and $150 \mathrm{cc} / \mathrm{min}$ carbon dioxide were added to produce the air $/ \mathrm{O}_{3}$ or $95 \% \mathrm{O}_{2} / \mathrm{O}_{3}$ atmospheres. The exhaust lines from the air $/ \mathrm{O}_{3}$ and the $95 \% \mathrm{O}_{2} / \mathrm{O}_{3}$ exposure vessels were connected to the ozone analyzer (Model 1003-AH, Dasibi Environmental Corp.) inlet and exhaust so that 2 liters/min of the atmospherc was circulated through and sampled by the analyzer. The analyzer was calibrated with an absolute ozone photometer (Model 1008-PC, Dasibi Environmental Corp.) according to the national reference method for ozone analyzer calibration (Environmental Protection Agency, 1980). During exposures, concentration data from the ozone analyzer were collected every $10 \mathrm{~min}$ with a computer-based data acquisition system that was also used to produce statistical reports on the exposure conditions. The desired ozone concentration of $1 \mathrm{ppm}$ was achieved with a standard deviation of $5 \%$ of the mean. High peak excursions of the concentration, which could intluence the biological effects more than the mean level, were avoided.

Microscopic analysis. Transverse sections of the membranous portion of the tracheas were prepared for lightand electron-microscopic examination by means of previously published methods (Nikula et al., 1988). Specimens for quantitative ultrastructure were coded and viewed randomly with a Zeiss Model EM-10 transmission electron microscope, and montages were prepared by photographic enlargement to $4080 \times$ on $8 \times 10$-in. prints. Cell counts were estimated by classifying the cell type of the central 200 nuclear profiles in the specimen. The numerical density (nuclei/mm) was determined by normalizing the cell counts to the length of the corresponding basement membrane measured using a Zeiss Videoplan image analyzer.

Statistical analysis of data. The numerical density data were processed for statistical analysis (one-way analysis of variance and Tukey studentized range method) with SAS software and a VAX 11/780 minicomputer. Probability used as criterion for significance was less than 0.05 .

\section{RESULTS}

Fifteen morphologic categories of normal or damaged cells were distinguished (Table 1). The undamaged ciliated, serous, basal, brush, and migratory cells were identified by standard criteria (Jeffery and Reid, 1975; Plopper et al., 1983; Pearsall et al., 1984).
Damaged ciliated cells were categorized as damaged-cilia, degenerate, or necrotic cells, and damaged serous cells were categorized as degenerate or necrotic. These categories of cells, as well as the identification of the intermediate cells, unidentified cells, necrotic unidentified cells, and sloughed cells, were based on criteria previously described (Nikula et al., 1988). The intermediate cells in this study are similar to those obscrved previously in rat respiratory epithelium and appear to represent immature cells, mostly preciliated cells (Jeffrey and Reid, 1975; Breeze and Wheeldon, 1977). The metaplastic cells were polyhedral, their longest axis was parallel to the basal lamina, and they were located in the middle stratum of stratified epithelia. The most prominent cytoplasmic feature of these cells was the presence of numerous cytoplasmic tonofilaments. Numerous desmosomes attached these cells to neighboring cells. These cells had few profiles of endoplasmic reticulum and lacked secretory granules. The cytoplasmic electron density was greater than that of typical serous or ciliated cells. Metaplastic cells were distinguished from serous cells by their lack of secretory granules, presence of numerous tonofilaments but few profiles of endoplasmic reticulum, stratification, and lack of a columnar shape with orientation perpendicular to the basal lamina.

The tracheal organ cultures exposed to filtered air had pseudostratified, columnar, ciliated, epithelia (Fig. 1A). The predominant cell types were serous cells, basal cells, and ciliated cells (Fig. 2A). These cells were well differentiated and could be readily distinguished from one another. The epithelia from the cultures exposed to air $/ \mathrm{O}_{3}$ were also pseudostratified and columnar, but they were nonciliated or sparsely ciliated (Fig. 1B). Damaged-cilia cells and intermediate cells were evident (Fig. 2B). Rarely, the basal cells appeared mildly enlarged. The $95 \% \mathrm{O}_{2}$-exposed epithelia were thicker than those from the air- or air $/ \mathrm{O}_{3}$-exposed groups (Fig. 1C). The $95 \% \mathrm{O}_{2}$-exposed epithelia were predomi- 
TABLE 1

Comparison of the Numeric Density (CElls/mm) Of Tracheal Epithelial Cells in Organ Cultures EXPOSED TO VARIOUS EXPERIMENTAL ATMOSPHERES

\begin{tabular}{|c|c|c|c|c|}
\hline \multirow[b]{2}{*}{ Category of cell } & \multicolumn{4}{|c|}{ Exposure regimen } \\
\hline & Filtered air & $\begin{array}{l}\text { Filtered air plus } \\
1 \text { ppm ozone }\end{array}$ & $\begin{array}{c}95 \% \text { oxygen, } \\
5 \% \text { carbon dioxide }\end{array}$ & $\begin{array}{l}95 \% \text { oxygen, } \\
5 \% \text { carbon dioxide } \\
\text { plus } 1 \text { ppm ozone }\end{array}$ \\
\hline Total cells & $224.50 \pm 15.73^{a}$ & $228.03 \pm 9.17$ & $305.53 \pm 18.71^{b}$ & $289.68 \pm 22.01$ \\
\hline Total ciliated cells & $21.16 \pm 6.91$ & $9.45 \pm 4.14$ & $20.11 \pm 2.50$ & $3.68 \pm 2.21$ \\
\hline Undamaged & $20.74 \pm 6.97$ & $5.73 \pm 2.45$ & $20.11 \pm 2.50$ & $2.89 \pm 1.82^{c}$ \\
\hline Damaged-cilia & $0.42 \pm 0.25$ & $3.06 \pm 2.07$ & $0.00 \pm 0.00$ & $0.44 \pm 0.44$ \\
\hline Degenerate & $0.00 \pm 0.00$ & $0.67 \pm 0.28$ & $0.00 \pm 0.00$ & $0.35 \pm 0.35$ \\
\hline Necrotic & $0.00 \pm 0.00$ & $0.00 \pm 0.00$ & $0.00 \pm 0.00$ & $0.00 \pm 0.00$ \\
\hline Total serous cells & $138.31+15.93$ & $146.68+12.64$ & $222.04+15.08^{d}$ & $160.91 \pm 8.61$ \\
\hline Undamaged & $137.46 \pm 16.12$ & $143.84 \pm 12.30$ & $221.09 \pm 14.85^{d}$ & $152.87 \pm 6.68$ \\
\hline Degenerate & $0.86 \pm 0.60$ & $2.24 \pm 0.78$ & $0.37 \pm 0.37$ & $5.91 \pm 1.22^{d}$ \\
\hline Necrotic & $0.00 \pm 0.00$ & $0.61 \pm 0.61$ & $0.57 \pm 0.57$ & $2.13 \pm 1.86$ \\
\hline Basal cells & $52.35 \pm 6.47$ & $42.53 \pm 4.10$ & $33.40 \pm 3.21$ & $27.15 \pm 6.91^{\circ}$ \\
\hline Intermediate cells & $0.00 \pm 0.00$ & $8.55 \pm 3.06$ & $11.38 \pm 4.25^{e}$ & $0.72 \pm 0.46$ \\
\hline Metaplastic cells & $0.50 \pm 0.50$ & $3.37 \pm 1.74$ & $3.80 \pm 1.54$ & $73.11 \pm 12.93^{d}$ \\
\hline Brush cells & $0.63 \pm 0.42$ & $0.42 \pm 0.26$ & $0.66 \pm 0.41$ & $1.34 \pm 0.82$ \\
\hline Total migratory cells & $8.54 \pm 3.86$ & $11.07 \pm 3.50$ & $5.79 \pm 3.03$ & $12.14 \pm 4.92$ \\
\hline Unidentified cells & $2.38 \pm 0.70$ & $3.90 \pm 1.43$ & $3.83 \pm 0.62$ & $4.16 \pm 1.09$ \\
\hline Necrotic (unidentified) & $0.41 \pm 0.41$ & $1.62 \pm 0.81$ & $1.51 \pm 0.93$ & $3.58 \pm 0.91$ \\
\hline Sloughed cells & $0.20 \pm 0.20$ & $0.42 \pm 0.26$ & $0.00 \pm 0.00$ & $4.18 \pm 1.45^{d}$ \\
\hline
\end{tabular}

nantly ciliated, pseudostratified, and columnar, but there were focal areas of apparent stratification. The predominant cell types were serous cells, basal cells, and ciliated cells (Fig. 2C). Intermediate cells were present in each of these epithelia. The basal cells were enlarged, cuboidal, and had large nuclei.
These nuclei had a stippled chromatin pattern and prominent nucleoli. Mitotic figures were evident in two of these epithelia. The epithelia from the cultures exposed to $95 \% \mathrm{O}_{2} /$ $\mathrm{O}_{3}$ were thicker than those exposed to air or air $/ \mathrm{O}_{3}$ and appeared stratified (Fig. 1D). Large cuboidal basal cells and the basilar por-

FIG. 1. Representative light micrographs of cultured tracheal epithelia exposed to air, air plus 1 ppm $\mathrm{O}_{3}$ (air $/ \mathrm{O}_{3}$ ), $95 \% \mathrm{O}_{2}$, or $95 \% \mathrm{O}_{2}$ plus 1 ppm $\mathrm{O}_{3}\left(95 \% \mathrm{O}_{2} / \mathrm{O}_{3}\right)$. $\times 720$. (A) Air-exposed epithelium. This epithelium is pseudostratified, columnar, and ciliated. (B) Air $/ \mathrm{O}_{3}$-exposed epithelium. Note the sparse cilia. (C) $95 \% \mathrm{O}_{2}$-exposed epithelium. This epithelium is pseudostratified, columnar, and ciliated. It is thicker than the air- or air $/ \mathrm{O}_{3}$-exposed epithelia. (D) $95 \% \mathrm{O}_{2} / \mathrm{O}_{3}$-exposed epithelium. This thick, stratified, nonciliated epithelium exhibits a focus of sloughed cells. 

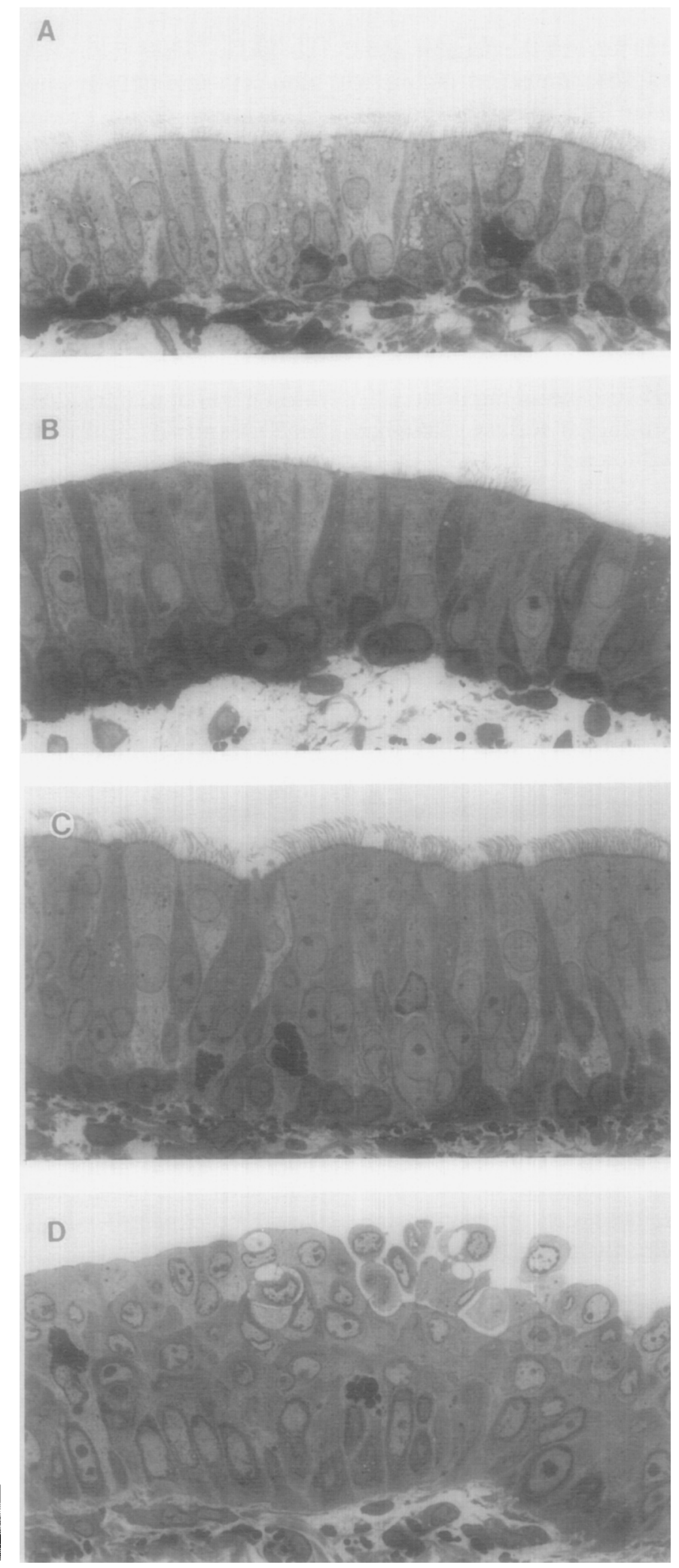
tions of serous cells formed the deepest layer. The next stratum was composed of one to three layers of metaplastic cells. The most superficial layer consisted of columnar or cuboidal serous cells and rare ciliated cells (Fig. 2D). These epithelia were nonciliated or very sparsely ciliated. The predominant cell types were serous cells, metaplastic cells, and basal cells. Focal aggregates of adherent necrotic cells (categorized as sloughed cells) were located in areas where the superficial columnar layer was missing and the metaplastic cells extended to the epithelial surface. Sloughed cells were attached to each of the $95 \% \mathrm{O}_{2} / \mathrm{O}_{3}$ epithelia.

Quantitation of cell densities revealed several differences among the four groups in the response of the tracheal epithelium to the various experimental atmospheres (Table 1). The $95 \% \mathrm{O}_{2}$-exposed group exhibited a significant increase in the total cell density and a concomitant increase in total serous cell density compared to the air- and air $/ \mathrm{O}_{3}$-exposed groups. The intermediate cell density was also significantly increased in the $95 \%$ $\mathrm{O}_{2}$-exposed group compared to the air-exposed group. The total cell density increased in the $95 \% \mathrm{O}_{2} / \mathrm{O}_{3}$ group compared to the air and air/ $\mathrm{O}_{3}$ groups, but this difference had not quite reached the statistical significance level. The undamaged ciliated cell population was significantly decreased in the $95 \% \mathrm{O}_{2} / \mathrm{O}_{3}$-exposed group compared to the two groups that had not been exposed to ozone. The densities of degenerate serous cells and sloughed cells were significantly increased in the $95 \% \mathrm{O}_{2} /$ $\mathrm{O}_{3}$-exposed group compared to the other three groups. The basal cell population was significantly smaller than that of the filtered air group, while the metaplastic cell population was significantly larger in the $95 \% \mathrm{O}_{2} /$ $\mathrm{O}_{3}$-exposed group compared to the other three groups. In the air $/ \mathrm{O}_{3}$-exposed group, the total ciliated cell population decreased compared to the two groups not exposed to ozone, and a third of the ciliated cell population exhibited damaged cilia, but the density changes did not quite reach the statistical significance level. When calculated as a proportion of the total ciliated cell population, the proportion of undamaged ciliated cells in the air $/ \mathrm{O}_{3}$-exposed group $(40.4 \%)$ was significantly decreased $(p<0.05)$ compared to the air-exposed group (97.4\%).

\section{DISCUSSION}

Three types of responses to the oxidant atmospheres used in this study are evident. One response is oxygen-induced epithelial hyperplasia. The second response is ozone-induced loss of ciliated cells and cell damage. The third response is a synergism between ozone and oxygen leading to enhanced epithelial injury and metaplasia.

The main effect of the $95 \% \mathrm{O}_{2}$ atmosphere was an epithelial hyperplasia which was primarily due to an increased serous cell density. The increased cell density was interpreted to be a hyperplastic response rather than considering the response to the filtered air as cell loss. The oxygen-induced response was accompanied by focal apparent stratification of serous cells, an increased density of intermediate cells, and occasional mitotic figures, as would be expected with hyperplasia, while the response to filtered air was not character-

FIG. 2. Representative electron micrographs of cultured tracheal epithelia exposed to air, air plus 1 ppm $\mathrm{O}_{3}\left(\mathrm{air} / \mathrm{O}_{3}\right), 95 \% \mathrm{O}_{2}$, or $95 \% \mathrm{O}_{2}$ plus $1 \mathrm{ppm} \mathrm{O}_{3}\left(95 \% \mathrm{O}_{2} / \mathrm{O}_{3}\right)$. $\times 2000$. (A) Air-exposed epithelium. Serous cells (s), basal cells (b), and ciliated cells (c) are readily identified. (B) Air/O $\mathrm{O}_{3}$-exposed epithelium. A damaged-cilia cell (dc) with sparse, broken cilia and an intermediate cell (i) are illustrated. (C) $95 \% \mathrm{O}_{2}$-exposed epithelium. Ciliated (c), serous (s), and basal (b) cells are easily identified. An intermediate cell (i) is present. (D) $95 \% \mathrm{O}_{2} / \mathrm{O}_{3}$-exposed epithelium. There is a middle zone composed of metaplastic cells (m). Ciliated cells are not identified in the superficial layer. 
A

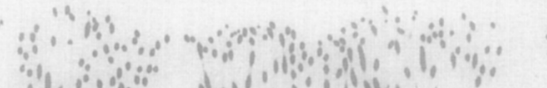

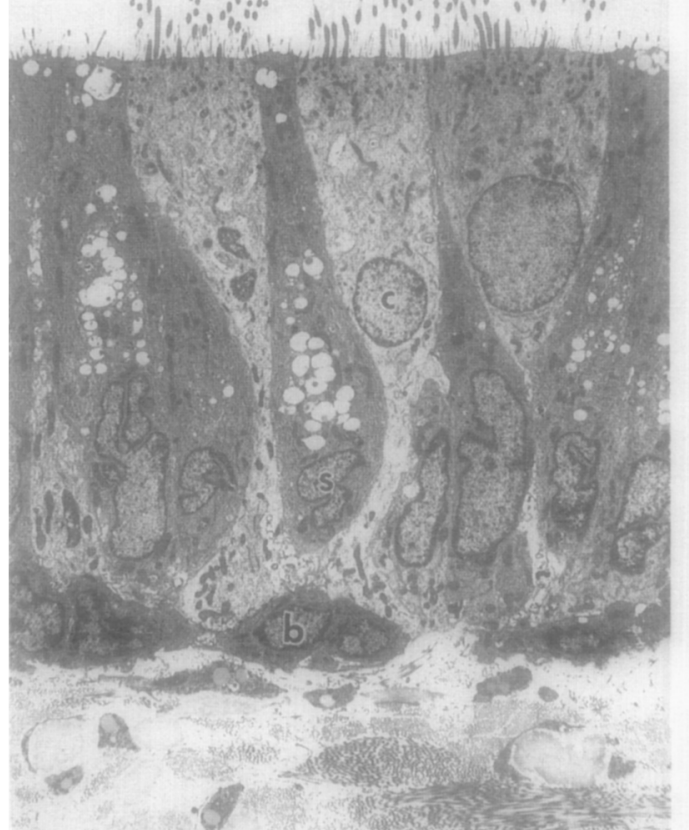
虾

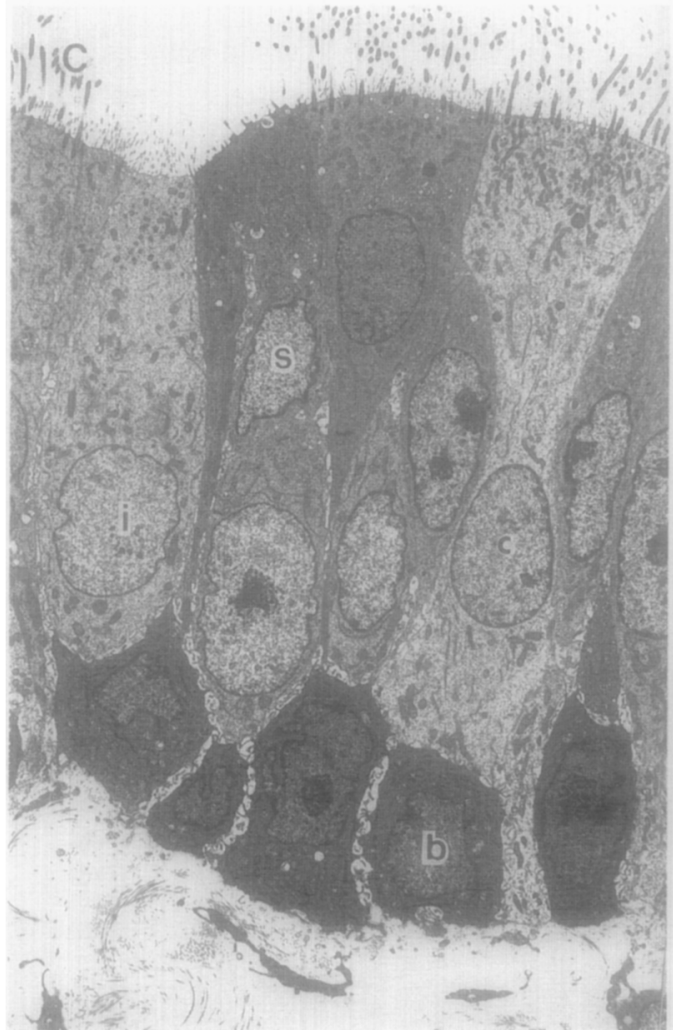

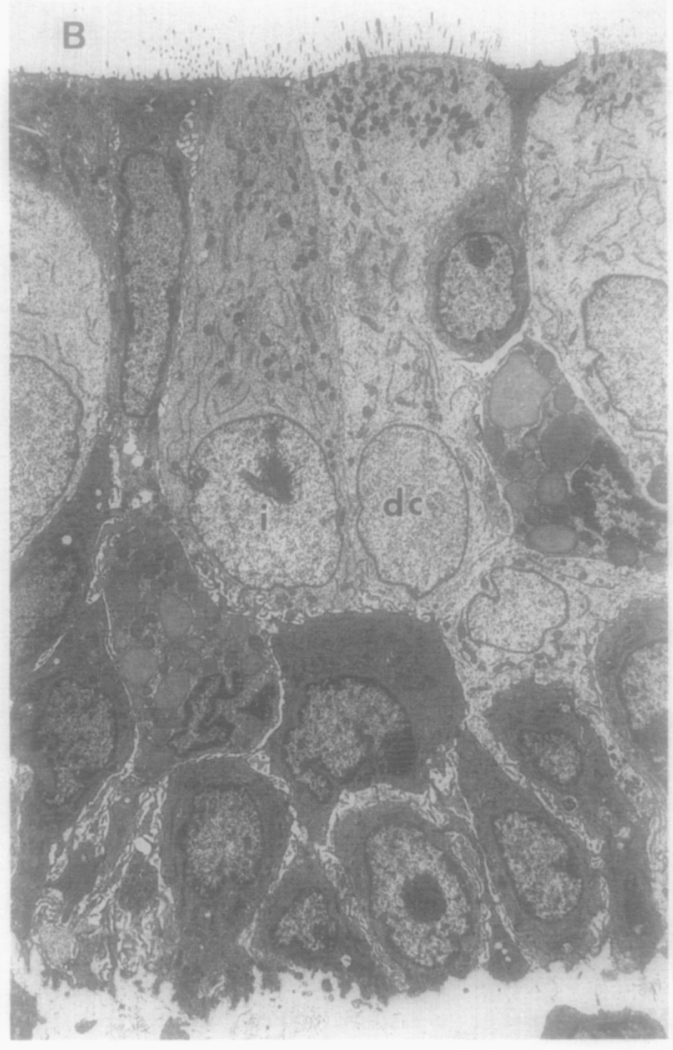

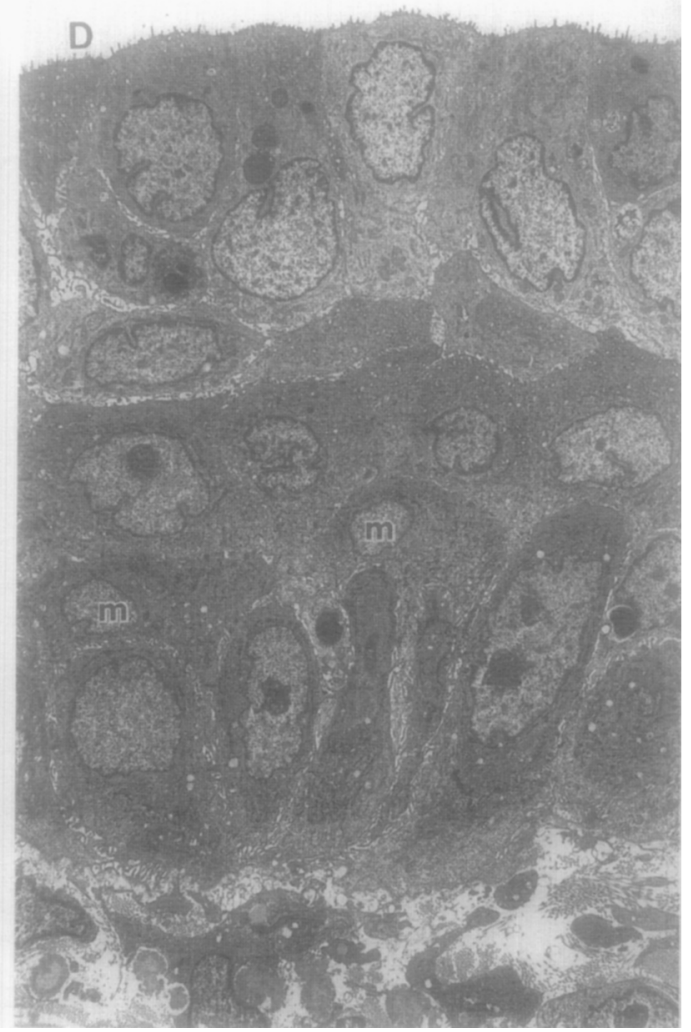


ized by significant cell damage, necrosis, and sloughing, as would be expected with cell loss.

The ciliated cell population density was the same in the $\mathrm{O}_{2}$-exposed epithelia as in the airexposed epithelia. The presence of intermediate cells, many of which appeared to be preciliated cells, suggests that ciliated cell differentiation was occurring at this time point. The lack of evidence of ciliated cell damage further suggests that the ciliated cell population was not undergoing repair in response to injury, but instead that the presence of intermediate cells was a consequence of the hyperplastic response. Boat et al. (1973) observed foci of squamous mctaplasia, degencration, and only a few ciliated cells after exposing cultured tracheas from human neonates to $80 \%$ oxygen for $96 \mathrm{hr}$. We did not observe similar damage in the rat tracheas exposed to $95 \%$ oxygen. We did observe focal stratification of serous cells, but not metaplasia, in 95\% oxygen-exposed epithelia. An earlier ultrastructural study of rat tracheal epithelium cultured in a $95 \% \mathrm{O}_{2}$ atmosphere concluded that the ultrastructure of the epithelium was well preserved for periods up to 4 days ( $\mathrm{Pa}$ velka, 1976). In that study there was a slight reduction in ciliary density in some ciliated cells, while a normal distribution of cilia was found in others. The differences between Boat's observations and those of Pavelka and us may indicate that rat tracheal epithelium is less sensitive than human tracheal epithelium to oxygen-induced damage, or the disparity may be due to differences in culture technique.

The response to ozone was manifest by loss of ciliated cells and ciliated cell damage. The changes in ciliated cell numerical density did not reach the 0.05 statistical significance level in air $/ \mathrm{O}_{3}$-exposed epithelia, but the proportion of undamaged ciliated cells was significantly reduced. There was a significant decrease in the undamaged ciliated cell density in the $95 \% \quad \mathrm{O}_{2} / \mathrm{O}_{3}$-exposed epithelia. The trend toward epithelial damage is clearly evident when either of the nonozone-exposed groups is compared to the air $/ \mathrm{O}_{3}$ and $95 \% \mathrm{O}_{2} /$ $\mathrm{O}_{3}$ groups.

There was a synergism between the ozone and high oxygen concentration exposure which led to enhanced epithelial damage. Oxygen exposure alone caused no evidence of cell injury compared to the filtered air exposure, while the ozone plus filtered air exposure led to a subjective evidence of cellular degeneration. In the $95 \% \mathrm{O}_{2} / \mathrm{O}_{3}$ group, however, there was a significant decrease in undamaged ciliated cells over that in the filtered air or $95 \% \mathrm{O}_{2}$ groups and a significant increase in both degenerate serous cells and sloughed cells compared to the other groups. The cellular antioxidant systems may be the critical determinants of the degree of epithelial injury occurring upon exposure to these oxidants. Several biochemical studies of lung tissue from animals exposed to acute high levels of ozone or oxygen have shown oxidation of sulfhydryl-containing compounds and inhibition of enzyme activities (Mustafa and Tierney, 1978; Frank, 1985). Perhaps the cellular antioxidant mechanisms were adequate to protect the cells when each oxidant was administered independently, but combined exposure overwhelmed these mechanisms and exceeded the threshold for the injury to be recognized morphologically. Cross-tolerance experiments have illustrated the interactions between these oxidants and the antioxidant enzyme levels (Jackson and Frank, 1984).

We have used the term metaplastic cell to categorize cells which shared certain morphologic features and which are not found in the uninjured pseudostratified columnar epithelium of the rat trachea. These metaplastic cells formed a distinct middle stratum within the $\mathrm{O}_{2} / \mathrm{O}_{3}$-exposed epithelia. The metaplastic cells in these epithelia shared features with the metaplastic cells described in organ cultures maintained for 3 and 5 weeks in unsupplemented CMRL 1066 medium (Sigler et al., 1987, 1988). These cells are stratified, polyhedral, and extend from the basement 
membrane toward the lumen (Sigler et al., 1987). Ultrastructural features include tonofilament bundles, numerous desmosomal attachments, moderately developed rough endoplasmic reticulum, and profiles of Golgi apparatus (Sigler et al., 1988). Unlike the metaplastic cells observed by Sigler $e t$ al., the metaplastic cells we observed did not form keratin pearls nor did they cornify and desquamate from the surface. Metaplastic cells have been seen when tracheal epithelium derived from nondeficient rats is maintained in vitamin A-deficient medium, but not until approximately 4 weeks or longer in culture (Marchok et al., 1975; Clark and Marchok, 1979).

The metaplastic cells in this study could represent cells which are differentiating from a progenitor cell, either basal or secretory, or they could represent dedifferentiation of a differentiated cell type. The presence of rough endoplasmic reticulum and Golgi apparatus was considered by Sigler et al. to be evidence that the metaplastic cells were altered secretory cells. The possibility that these altered cells are derived from basal cells must also be considered. Previous organ explant culture studies have concluded that metaplastic foci arise from hyperplastic basal cells (Palekar et al., 1968; Mossman and Craighead, 1975; Lane and Miller, 1976; Chopra 1982; Chopra and Cooney, 1985). The basal cells in the $\mathrm{O}_{2} /$ $\mathrm{O}_{3}$-exposed epithelia appeared hypertrophied, but the population density of cells identified as basal cells was decreased. There was a concomitant increase in the metaplastic cell population within these epithelia. At the same time, cells with features intermediate between the metaplastic cells and serous cells were observed. It has been noted (Chang et al., 1985) that secretory cells in mixed rat tracheal cell cultures lose their secretory granules and all ultrastructural features characteristic of secretory cells. As suggested hy Inayama et al. (1988), if a similar dedifferentiation can occur in vivo or in organ culture, then it will be difficult to accurately morpho- logically distinguish altered secretory cells and basal cells.

There are similarities between the in vivo and in vitro responses of the rat tracheal epithelium to ozone exposure. After 3 days of $0.96 \mathrm{ppm}$ ozone exposure in vivo, the tracheal epithelium is not hyperplastic, but does exhibit an increased density of damaged-cilia cells, intermediate cells, and unidentified necrotic cells (Nikula et al., 1988). Likewise, in vitro exposure to air plus $1 \mathrm{ppm}$ ozone did not result in hyperplasia in this study, but did lead to the same trends in cell density changes although these changes did not reach the statistical significance level. The differences between the degree of ozone-induced injury in vivo and in vitro appear to be more a consequence of the greater statistical variability in the in vitro results than due to dissimilarities in biological response. The lack of an inflammatory response in the culture system might account for the slight disparity in degree of injury between the in vivo and in vitro results. Differences in the thickness and antioxidant capabilities of the fluid layer (tracheal mucus versus culture medium) could also result in a difference in effective dose at the cell level.

The in vivo and in vitro responses to high oxygen exposure cannot be directly compared since we were unable to find reports of tracheal epithelial cell population responses to oxygen exposure. There is one ultrastructural study of the effects on the trachea of 12and 24 -hr exposures of rats to $100 \%$ oxygen (Heino and Laitinen, 1982). The main findings were that the epithelia and cilia of the oxygen-exposed rats remained intact, but that fibrogranular areas and basal bodies were found in the cytoplasm of numerous ciliated and preciliated cells. Similarly, we found an increased population of intermediate cells (mostly preciliated cells) in the $95 \%$ oxygenexposed epithelia. Another ultrastructural study of the effects of $100 \%$ oxygen exposure in vivo on the rat trachea (Philpott et al., 1977) also noted that the cilia remain intact 
after $72 \mathrm{hr}$. However, these investigators noted blebs in ciliary membranes and swelling of nonciliated cells. These later findings would suggest more severe injury in vivo than in vitro.

The similarities between the in vivo and the in vitro response to ozone, as well as the differences in the response to ozone versus oxygen exposure in vitro, suggest that the organ culture system may be useful in the study of the effects of these oxidants on respiratory epithelium. The organ culture may be especially useful in separating the direct effects of these toxicants from the secondary effects of the inflammatory response induced in vivo.

\section{ACKNOWLEDGMENTS}

The authors thank S. Dunston and B. Tarkington for technical assistance and I-Yiin Chang for advice on statistical methods. This research was supported by PHS Grant ESO0628 and, in part, by the Office of Health and Environmental Rescarch, U.S. Department of Energy, under contract DEAC04-76EV01013.

\section{REFERENCES}

Bost, T. F. (1979), Studies of oxygen toxicity in cultured human neonatal respiratory epithelium. J. Pediatr. 95(5, pt. 2), 916-919.

Boat, T. F., Kleinerman, J. I., Fanaroff, ^. ^., AND MATTHEWS, L. W. (1973). Toxic effects of oxygen on cultured human neonatal respiratory epithelium. $P e$ diatr. Res. 7, 607-615.

BREEZE, R. G., AND WHEELdon, E. B. (1977). The cells of the pulmonary airways. Amer. Rev. Respir. Dis. 116, 705-777.

Chang, L-Y., Wu, R., and Nettesheim, P. (1985). Morphologic changes in rat tracheal cells during the adaptive and early growth phase in primary cell culture. J. Cell Sci. 74, 283-301.

Chopra, D. P. (1982). Squamous metaplasia in organ cultures of vitamin A-deficient hamster trachea: Cytokinetic and ultrastructural alterations. $J$. Natl. Cancer Inst. 69, 895-905.

Chopra, D. P., And CoOney, R. A. (1985). Histogenesis of benzo( $a)$ pyrene-induced lesions in tracheal explants. Virchows Arch. [Cell Pathol.] 48, 299-315.

Clark, J. N., AND MarChOK, A. C. (1979). The effect of vitamin $A$ on cellular differentiation and mucous glycoprotein synthesis in long-term rat tracheal organ cultures. Differentiation 14, 175-183.
Environmental Protection Agency (1980). Protection of the Environment. United States Code of Federal Regulations 40, 537-541.

Frank, L. (1985). Oxygen Toxicity in Eukaryotes. In Superoxide Dismutase. Volume III: Pathological States (L. W. Oberley. Ed.), pp. 2-43. CRC Press, Boca Raton, FL.

Grose, E. C., Gardner, D. E., and Miller, F. J. (1980). Response of ciliated epithlium to ozone and sulfuric acid. Environ. Res. 22, 377-385.

Harkema, J. R., Plopper, C. G., Hyde, D. M., St, George, J. A., Wilson, D. W., and DUNGWORTH, D. L. (1987). Response of the Macaque nasal epithelium to ambient levels of ozone. A morphologic and morphometric study of the transitional and respiratory epithelium. Amer. $J$. Pathol. 128(1), 2944.

I IEINO, M., AND LAITINEN, L. A. (1982). Oxygen exposure and extrapulmonary respiratory tract ciliogenesis in adult male rats. Aviat. Space Environ. Med. 53(6), 580-582.

Inayama, Y., Hook, G. E. R., BRody, A. R., CAMERON, A. M., JETTEN, L. B., GRAY, T., AND NETTESHEIM, P. (1988). The differentiation potential of tracheal basal cells. Lab. Invest. 58(6), 706-717.

JACKSON, R. M., AND FRANK, L. (1984). Ozone induced tolerance to hyperoxia in rats. Amer. Rev. Respir. Dis. 129, 425-429.

JEFFERY, P. K., AND REID, L. (1975). New observations of rat airway epithelium: A quantitative electron microscopic study. J. Anat. 120(2), 295-320.

LANE, B. P., AND Miller, S. L. (1976). Carcinogen-induced changes in tracheal epithelium cultured in serum-free, chemically defined medium. J. Natl. Cancer Inst. 56, 75-86.

LAST, J. A., Jennings, M. D., SChwartz, L. W., AND CROSS, C. E. (1977). Glycoprotein secretion by tracheal explants cultured from rats exposed to ozone. Amer. Rev. Respir. Dis. 116, 695-703.

MarChok, A. C., Cone, M. V., and Nettesheim, P. (1975). Induction of squamous metaplasia (vitamin A deficiency) and hypersecretory activity in tracheal organ cultures. Lab. Invest. 33(4), 451-460.

Morgan, D. L., AND Wenzel, D. G. (1985). Free radical species mediating the toxicity of ozone for cultured rat lung fibroblasts. Toxicology 36, 243-251.

Mossman, B. T., and Craighead, J. E. (1975). Longterm maintenance of differentiated respiratory epithelium in organ culture 1. Medium composition. Proc. Soc. Exp. Biol. Med. 149, 227-233.

Mustafa, M. G., AND Tierney, D. F. (1978). Biochemical and metabolic changes in the lung with oxygen, ozone, and nitrogen dioxide toxicity. Amer. Rev. Respir. Dis. 118(6), 275-304.

Nikula, K. J., Wilson, D. W., Giri, S. M., Plopper, C. G., AND DungworTh, D. L. (1988). The response 
of the rat tracheal epithelium to ozone exposure: Injury, adaptation, and repair. Amer. J. Pathol. 131(2), 373-384.

PalekAR, L., Kuschner, M., AND Laskin, S. (1968). The effect of 3-methylcholanthrine on rat trachea in organ culture. Cancer Res. 28, 2098-2104.

Pavelka, M. (1976). Organ culture of adult rat and mouse tracheal epithelium. I. Ultrastructure following various culture periods. Cell Tissue Res. 165, 371382.

Pearsall, A. D., Echt, R., Ross, L. M., Roth, R. A., JR., AND DINNERSTEIN, R. J. (1984). Morphologic and cytochemical characteristics of amine-containing globule leukocytes in rat tracheal epithelium. Amer. $J$. Anat. 170, 83-99.

Philpott, D. E., Harrison, G. A., Turnbill, C., AND BLACK, S. (1977). Ultrastructural changes in tracheal epithelial cells exposed to oxygen. Aviat. Space Environ. Med. 48(9), 812-818.

Plopper, C. G., Mariassy, A. T., Wilson, D. W., AlLEY, J. L., NISHO, S. J., AND NeTTERShEIM, P. (1983). Comparison of nonciliated tracheal epithelial cells in six mammalian species: Ultrastructure and population densities. Exp. Lung Res. 5, 281-294.
RASMUSSEN, R. E. (1984). In vitro systems for exposure of lung cells to $\mathrm{NO}_{2}$ and $\mathrm{O}_{3} . J$. Toxicol. Environ. Health 13(2-3), 397-411.

SACKNer, M. A., Hirsch, J. A., Epstein, S., AND RywLIN, A. M. (1976). Effect of oxygen in graded concentrations upon tracheal mucus velocity. A study in anesthetized dogs. Chest 69(2), 164-167.

SACKNER, M. A., LANDA, J., HiRSCH, J. A., ZapatA, A (1975). Pulmonary effects of oxygen breathing: A sixhour study in normal men. Ann. Intern. Med. 82, 40-43.

Sigler, R. E., JONES, R. T., Hebel, J. R., AND MCDOWELL, E. M. (1987). J Jamster tracheal organ culture in serum-free media: A quantitative comparison of in vitro epithelial morphology with that of in vivo controls In Vitro Cell. Dev. Biol. 23(2), 100-110.

Sigler, R. E., NewKIRK, C., AND MCDowell, E. M. (1988). Histiogenesis and morphogenesis of epidermoid metaplasia in hamster tracheal organ explant culture. Virchows Archiv. $B$ [Cell Pathol.] 55, 47-55.

Wilson, D. W., Plopper, C. G.. ANd Dungworth, D. L. (1984). The response of the macaque tracheobronchial epithelium to acute ozone injury: A quantitative ultrastructural and autoradiographic study. Amer. J. Pathol. 116, 193-206. 